\begin{tabular}{|c|c|c|c|c|c|c|}
\hline \multirow[b]{2}{*}{$\begin{array}{l}\text { Sample } \\
\text { No. }\end{array}$} & \multirow[b]{2}{*}{$\begin{array}{l}\text { Van } \\
\text { Slyke }\end{array}$} & \multicolumn{4}{|c|}{ CONCENTRATION (MG./100 ML.) } & \multirow[b]{2}{*}{$\begin{array}{l}\text { Spectronic } \\
\text { Reading } \\
\text { at } \\
435 \mathrm{~nm} \text {. }\end{array}$} \\
\hline & & $\begin{array}{l}\text { Watt and } \\
\text { Chrisp } \\
\text { Reading } \\
\text { at } \\
420 \mathrm{~nm} .\end{array}$ & $\begin{array}{l}\text { Watt and } \\
\text { Chrisp } \\
\text { Reading } \\
\text { at } \\
435 \mathrm{~nm} .\end{array}$ & $\begin{array}{l}\text { Sample } \\
\text { No. }\end{array}$ & $\begin{array}{l}\text { Uvispec } \\
\text { Reading } \\
\text { at } \\
435 \mathrm{~nm} .\end{array}$ & \\
\hline 1 & 19 & 30 & 14 & 1 & 28 & 29 \\
\hline 2 & 41 & 73 & 38 & 2 & 28 & 30 \\
\hline 3 & 97 & 126 & 102 & 3 & 21 & 24 \\
\hline 4 & 32 & 50 & 28 & 4 & 29 & 31 \\
\hline 5 & 97 & 137 & 107 & 5 & 21 & 36 \\
\hline 6 & 72 & 103 & 70 & 6 & 146 & 141 \\
\hline 7 & 29 & 38 & 21 & 7 & 126 & 116 \\
\hline 8 & & & & 8 & 54 & 55 \\
\hline 9 & 116 & 155 & 133 & 9 & 185 & 178 \\
\hline 10 & 23 & 26 & 18 & 10 & 312 & 275 \\
\hline 11 & 27 & 17 & 23 & & & \\
\hline 12 & 48 & 47 & 47 & & & \\
\hline 13 & 36 & 55 & 29 & & & \\
\hline
\end{tabular}

With this valuable modification the method of Watt and Chrisp comes within the reach of laboratories with modest equipment and attains the same grade of accuracy as the other routine laboratory procedures for blood urea besides being much more suitable for routine clinical pathology than the other available methods.

It must, however, be emphasized that extreme care is necessary in preparing the reagents, that high quality distilled water is required, and that fresh reagent (4) has to be used every week.

\section{A method for the collection of saliva}

\section{P. J. COUSINS ${ }^{1}$ From the Hospital for SicR Children, Great Ormond Street, London}

The collection of saliva from normal adults and children $\overrightarrow{\vec{H}}$ unless they are very young-presents no difficulty, bu where the patient is unable to use (or, as in one cases considered it rude to spit for any reason) a sputun receiver the collection presents a problem.

During a study of saliva from children with phenyin ketonuria (Cousins, Philips, Stroud, Wise, and Woolf 1960), a simple method of collection was adopted. pasteur pipette with a bulb was cut short and a piece of polythene tubing of $2 \mathrm{~mm}$. bore affixed. The end of the polythene tube was warmed and pushed on to the pipett $\bar{z}$ tip, this having been similarly warmed; on cooling the joint was found to be very firm. The tubing was cut, so that its length was $6 \mathrm{~cm}$., the cut being diagonal across the tube. This end was warmed until pliable and therp squashed against a glass plate, thus forming a thickened and wide orifice approximately $4 \mathrm{~mm} . \times 2 \mathrm{~mm}$.

The patient was in one of two positions depending ore the degree of cooperation:

(1) The lateral position of the head while lying flat assistance in holding the head is necessary in cases of bact cooperation.

(2) Normal sitting position; assistance is necessary onl $\overrightarrow{\overrightarrow{0}}$ in the case of the very young.

The pipette is introduced $(a)$ to the cheek wall, and (b) under the tongue. Saliva can then be collected by normal pipettage. Amounts of the order of 2 to $3 \mathrm{ml}$ can be collected in a comparatively short time and transferred to a stoppered test-tube (Exelo $10 \mathrm{~cm} . \times 1 \mathrm{~cm} \frac{\mathrm{O}}{3}$ most useful).

The best times for collection are just before a feed or at least two hours afterwards, there being no con₹ tamination by food residues at these times.

The advantages of such a pipette are:

(1) Should the patient bite down on the pipette no harmo is done, the portion in the mouth being polythene.

(2) No trauma occurs using polythene.

(3) Stimulation of salivary glands is easily effected.

(4) Polythene is easily cleaned and the pipette is easily and quickly cleaned in water.

(5) Such a pipette has a longer life than an ordinary bulb pasteur pipette.

\section{REFERENCE}

Cousins, P. J., Phillips, S. J., Stroud, C. E., Wise, J., and Woolf, C L. (1960). Amino Acids of Sweat and Saliva in Phenylketonuria $\vec{\Phi}$ In preparation.

Received for publication 26 May 1960.

'Present address: Royal National Orthopaedic Hospital, Brockley Hill, Stanmore, Middlesex. 